\title{
The Concept of Lenition as the Phonemic Linguistic Phenomena
}

\author{
Azhar A. Alkazwini \\ The Public Authority of Applied Education (PAAET), Kuwait \\ E-mail: aasalkb@hotmail.com
}

Received: 18-06-2016

Published: 02-01-2017
Accepted: 20-08-2016

doi:10.7575/aiac.ijalel.v.6n.1p.29
Advance Access Published: November 2016

URL: http://dx.doi.org/10.7575/aiac.ijalel.v.6n.1p.29

\begin{abstract}
The term 'lenition' has numerous definitions offered in the Phonology of English language, some of which will be discussed in this study. Moreover, "Spirantization", "approximantization", "debuccalization" and "voicing" are changes that are counted as lenition. There are also different types of lenition, and different views regarding what lenitions have in common. Some phonologists perceive lenition as the loss of segmental material, while it is perceived by others as an increase in sonority (Honeybone 2012). With regards to lenition in the English Language, English does not have such widespread lenitions. There are other phenomena that can be regarded as lenition in the English Language, and this will be casted light on it further in the current paper.
\end{abstract}

Keywords: lenition, Phonology, English Language, Spirantization, Approximantization, Debuccalization, Weakening, Affrication of Plosives

\section{Introduction}

A number of definitions regarding the term 'lenition' can be found in the literature. In this paper, the researcher will present these various definitions, which include some current fundamentals about what lenition might actually be, then, what counts as lenition and some different types of lenition shall be discussed, and after that, what lenitions have in common shall be discussed. Section 5. is devoted to lenition in English Language; the contemporary coronal stops, medial d-spirantization, lenition in Liverpool English, and 'voicing' in the history of the English Language. Section 6. will shed light on the environments where lenition can and cannot occur shall be mentioned, the effect of melodic inhibition in medial d-spirantization and Liverpool lenition. Finally, this research supports the fact that the different environments in context do promote the different types of lenition.

\section{Current definitions of 'lenition'}

Definitions of 'lenition' are diverse. In the Oxford English Dictionary (2006), phonological lenition is defined as "The process or result of making or becoming lenis; softening of articulation." Where definitions are specific to theory, lenition is modelled differently. For example, in Mascaro (1984) it is a feature of 'spreading', in Harris (1990) it is the absence of 'privative features', and in Kirchner (1998) it is "re-ranking of LAZY and faithfulness constraints" (Honeybone 2008, p.11). There is some disagreement amongst phonologists regarding the types of segmental changes or processes represented by lenition. Lass (1984) and Honeybone (2002) regard the affrication of plosives as lenition, whereas Foley (1977) and Kirchner (1998) do not. However, there is a basic concept of lenition which is commonly accepted by phonologists. It includes some simple segmental changes (Honeybone 2008, p.12-16).

Some simple definitions regarding lenition; "'lenition' is synonym of 'weakening' in phonology, and this clearly implies a notion of consonantal 'strength'" (Honeybone 2008, p.09). There are a few sources that state that lenition and 'weakening' are synonyms. According to Odden (2005), lenition, or vowel weakening, "is the most common segmental interaction between vowels and consonants" (p.239).Common examples of lenition consist of voiceless stops becoming voiced, or the voicing and spirantisation of stops. According to Ashby and Maidment (2005, p.141), consonants can be classified on the bases of their 'strength' on strength scales. This means that the stronger a consonant is, the more different it is than a vowel, and the weaker the consonants is, it is considered more vowel-like. According to Szigetvari (2008), a theoretical definition of lenition and assimilation is "Delinking of a private feature, and assimilation is the spreading of a private feature"(p.107).

There are a number of issues that arise with the notion of lenition. Odden (2005) states that lenition is connected to inter-sonorant context, and the concept of 'strength scales' was promoted by Ashby and Maidment (2005). There are certain kinds of lenition that have been mentioned. One idea is lenition is linked to the amount of strength a consonant has. This means some consonants have more strength than others. The concept of lenition and weakening in ongoing studies is universal in terms of the definitions that are available in the literatures of theoretical phonology. Some examples are Carr (1993, p.24), Kenstowicz (1994,p.35), Ewen and Hulst (2001,p.13) and Gussmann (2002,p.137). 
With regards to historical linguistics, Hock (1991), Trask (1996), Hoch and Joseph (1996) and Campbell (1998) are some examples.

A definition of lenition found in Trask's (2000) Dictionary of Historical and Comparative Linguistics is "Lenition (also weakening): Any phonological change in which a segment becomes less consonant-like than previously. A shift in character from left to right along any of the scales in [figure (1)].. may be regarded as lenition.." (p.190). Szigetvari (2008) argues that "these scales are of limited explanatory value" (p.05).

\begin{tabular}{|c|c|c|c|c|c|}
\hline 6 & 5 & 4 & 3 & 2 & 1 \\
\hline $\begin{array}{l}\text { Voiceless } \\
\text { Stops }\end{array}$ & $\frac{\text { voiced stops }}{\text { voiceless fricatives }}$ & $\begin{array}{l}\text { voiced } \\
\text { fricatives }\end{array}$ & nasals & liquids & glides \\
\hline
\end{tabular}

Figure 1. Honeybone (2008, p.14)

In historical phonology, the concept of specific changes in segments which represent a comprehensive type of change is regarded as lenition. These changes form an ongoing process that consonants undergo. According to Honeybone (2008, p. 14), it was not that long ago that this term was first introduced. He believes that it was in the late nineteenth century that it was introduced.

There are a number of works that lenition was not mentioned in, namely Luick's (1914-1940) masterwork on English, and Dobson's (1957/1968) volumes on Early Modern English phonological change. A reason for this could be that it was due to changes in Celtic and Romance languages that brought about the development of the concept of lenition (Honeybone, 2012). The canon of English phonological change did not experience comparable phonological changes. According to Honeybone (2008), Martinet (1952, p.192) discusses lenition as "a type of process, which has language universal applicability, rather than just being a technical term of Celtic linguistics" (p.58).

Lenition has a substantial place in the literature of theoretical and historical phonology (Carvalho, Scheer and Segeral 2008). It is an important part of the work of Lass and Anderson (1975) and Harris (1994), where English consonantal phonology is discussed. It is now being associated with the phonological metaphors "softening" and "weakening", in addition to"soft" and "hard".

According to Honeybone (2008, p.17), many words such as 'soft', 'smooth', 'mild', 'gentle', 'easy', 'calm', 'moderate', 'lenient' were found in Latin-English dictionaries when he searched for possible translations of the word 'lenis', but none of the dictionaries mentioned the term 'weak' as a possibility.

\subsection{What counts as lenition}

According to Honeybone (2012), "spirantization", "approximantization", "debuccalization" (loss of oral articulation resulting in a glottal), and "voicing" are all kinds of changes that are regarded as lenition.

One of the main aims of lenition theory has been to consider these types of change as the 'same kind of thing', as there are linguistic commonalities, and, apart from in debuccalization, the place of articulation is the same. Whole natural classes of segments (all lenis stops) as well as single segments or segment pairs can be affected by the processes of lenition. Such changes occur in specific phonological environments. When the environment is seen in segments' surface distribution, the method of change involves a synchronic process. This enables the environment of an earlier synchronic process to "preserved in the distribution of contrasting segments in the words of a language" (Honeybone 2012, p.774).These kind of changes are recognized as lenition.

\subsection{Types of lenition}

According to Szigetvari (2008), lenition can be classified as:

a. "loss of place features: debuccalization: $[\mathrm{t}]>\left[\right.$ ?], $[\mathrm{f}]>[\mathrm{h}]$, depalatalization: $[\mathrm{n}]>[\mathrm{n}]$, delabialization: $\left[\mathrm{k}^{\mathrm{w}}\right]>[\mathrm{k}]$, etc.

b. loss of laryngeal features: devoicing: $[\mathrm{d}]>[\mathrm{t}]$, deaspiration: $\left[\mathrm{t}^{\mathrm{h}}\right]>[\mathrm{t}]$

c. sonorization: spirantization: $[\mathrm{t}]>[\theta]$, gliding: $[\mathrm{p}]>[\mathrm{w}]$, rhotacism: $[\mathrm{s}]>[\mathrm{r}]$, etc."(p.110).

\section{What do lenitions have in common?}

There are different views regarding what lenitions have in common. Some phonologists perceive lenition as the loss of segmental material, while it is perceived by others as an increase in sonority (Honeybone, 2012,p.775). Some phonologists have tried to associate lenitions with an increased "ease of articulation". There are many problems with these kind of definitions. One definition stems from Vennemann's claim that "a segment $\mathrm{X}$ is said to be weaker than a segment Y if Y goes through an X stage on its way to zero" (Hyman 1975,p.165). In some discussions regarding lenition, it is common for this notion to be quoted, as the notion is used to connect the different types of segments based on the "weakness" and "strength" of these segments on the scales of phonological strength. These hierarchies are known as 'lenition trajectories' and they project how the changes are connected to each other (Lass 1984, p.178).

According to Honeybone (2012), "Lass believes that affrication, spirantization, debuccalization .. and approximantization are linked to voicing .. as two sub-types of lenition: "opening" and "sonorizing" (p. 775). He notes 
that 'deletion' is the last stage of lenition, and this is represented by [Ø] on the lenition scale. According to Szigetvari (2008), some cases of lenition are controversial owing to these changes. There are other changes like glottalling, debuccalization to [?] that have also been added to this group, but Vennemann-Lass' idea is a more developed one, which gives us the basic and necessary idea.

Other arguments in the theory of lenition are related to the environments in which lenition can and cannot occur in contexts. According to Scheer and Segeral (2008), these positions are referred to as "strong" and "weak" positions. Weak positions are the positions that are thought to endorse lenition (i.e. they contain some feature that brings about lenition). Strong positions, on the other hand, are where lenition is not 'favoured'. These positions consist of word initial as in taktat, and post-coda position ([c._ ] taktat). The two positions are considered kinds of syllable onsets. Weak positions consists of codas and intervocalic positions (also known as 'medial'). The two types of codas are preconsonantal and word-final. Table (1) summarizes the strong and weak positions.

Table 1. Taken from Scheer and Segeral (2008)

\begin{tabular}{ccc}
\hline Strong (er) & Weak(er) & \\
\hline$[\#[]$ & {$[\ldots \mathrm{c}]$} & {$\left[\mathrm{v} \_\mathrm{v}\right]$} \\
{$\left[\mathrm{c} . \_\right]$} & {$[\ldots]$} & "intervocalic" \\
\hline Syllable-initial/ onset & Syllable-final/ coda & \\
Foot-initial / foot-head & & \\
\hline
\end{tabular}

Researchers must look into the intervocalic position for a couple of reasons. The first reason is that sonorous consonants and vowels could be on either side of this position. The other reason is that the position can be affected by the amount of stress around the syllable.

All kinds of intervocalic positions have some lenitions. This mainly realized in Romance Languages. Some occur only when there is an unstressed vowel pursuing the segment. In situations like this, lenition exists in a foot-medial segment, and does not occur in a foot-initial segment; tátat vs tatát. What can be concluded from this is that there are two kinds of intervocalic positions; 'stronger' [v_v́] and 'weaker'[ $\left.\hat{v}_{-} \mathrm{v}\right]$. That is not to say that all lenitions occur in all weak positions as a result of environmental restrictions. Some occur solely in intervocalic positions (sonorization), whereas others only occur in coda positions (debuccalization). Lenition can also take place in both of these positions, weak and strong.

\section{The idea of Lenition in English}

In comparison to Romance and Celtic, English does not have such widespread lenitions. There are other phenomena that can be regarded as lenition in the English Language. "A widespread synchronic sonorization, a spirantization that has left its mark on general English contrasts, a synchronic case of opening lenition from one dialect, and what look like historical voicings" (Honeybone 2012, p. 775).

\subsection{Contemporary coronal stops}

Carr and Honeybone (2007), note that "flapping" (tapping), an English phenomenon, is often considered lenition. Flapping has recently come about in Present Day English, and can be seen in Irish, Southern Hemisphere and the majority of American dialects, where the sounds /t/ and /d/ are affected and caused to sound more like [r], an alveolar flap.

The only environments where flapping can occur are constrained to medial/intervocalic positions, and in particularly, in weaker foot-internal positions ([v $\left.\left.\mathrm{v}_{-} \mathrm{v}\right]\right)$. The most significant feature is the absence of stress on the following syllable, as opposed to the preceding presence of stress.

A more accurate description for these kind of environments is to refer to it as 'intersonorant', rather than intervocalic. A reason for this is that flapping can occur with vowels or sonorous consonants that are nasal or rhotic on each side, as in party and pardon. In examples such as tip, dip and lid, it is clear that this process does not affect parts of the wordsedge. This is only the case if the words in the sentence do not have vowels surrounding them (Honeybone 2012, p.775).

The input of flapping is voiceless, and the output is 'lenis'. Because of this, some argue that by understanding the concept of lenition, it will be understood why flapping can be considered as lenition. Although it does not precisely follow Lass's lenition trajectory, a flap is generally perceived as more sonorous than a stop. "Flapping fits in with the environmental expectations for lenition processes, as long as the stress-based splitting of the medial environment is recognized" (Honeybone 2012, p. 776).Flapping is not the sole process affecting the realization of /t/. Some ways of leniting / $t$ / by several processes in various dialects have been characterised by Kallen (2005), Hickey (2009), and Harris (1994). Honeybone (2012) notes that in Liverpool lenition, /t/ is affected.

\subsection{Medial d-spirantization}

According to Dobson (1968, p.956), another phenomenon that is categorised as lenition involves coronal stop /d/. This phenomenon differs from flapping. "It is a change that has long reached the underlying representations of the language, and has left its mark on all reference varieties" (Honeybone 2012, p.776). 
The formula [d > ठ] symbolizes the change. Spirantization does not exist in word initial (day, dead) nor does it occur in coda position (wedlock). All positions where [ð] occur are medial. It can also occur in other environments such as intervocalic and intersonorant. Words like wonder and shoulder show that spirantization did not take place between any sonorants, and words like saddle and bladder are examples that's how it did not occur in a complete intervocalic environment. This is clear in the spelling of bladder and sadel in Middle English. Although these words had intervocalic lenis coronal stops, which is similar to the phonological environment of the word fader, the stops failed to spirantize. Dobson (1968, p.956) notes that for spirantization to occur, it is necessary for an / $\mathrm{r} /$ to follow in the word. The reason why this change did not take place in bladder is due to the fact that, at that time in the history of English, the coronal stop was a geminate, geminates usually "resist lenitions that affect their singleton congeners" (Honeybone 2012, p. 776).

Because this segmental condition requires a following / $r$, it should not be considered as lenition. The lenition environments are clear and do not require 'reference to segmental context'. Although I just mentioned the reason why this change should not be considered as lenition, it is more of lenition than it is of a flap (Honeybone 2012, p.777). Apart from it requiring a 'following / $r$ ', its environment meets all the criteria expected of lenitions, and it perfectly fits Lass's trajectory of lenition. It is not quite clear whether or not the foot-structure had any effect on this change.

\subsection{Lenition in Liverpool English}

In Liverpool English, the 'order of realizing the underlying stops' shows the aforementioned basic characteristics of lenition (Honeybone 2012, p. 777). According to Watson (2007), the salient stops that Liverpool lenition effects are /t/, $/ \mathrm{k} /$, and $/ \mathrm{d} /$. I shall give a brief description of the lenition of $/ \mathrm{t} /$ and $/ \mathrm{k} /$ as examples, but bear in mind that other stops may also lenite (Honeybone 2001; Watson 2006a; 2006b; 2007).

Based on a corpus based observation, Watson (2006a) states that in a non-debuccalizing environment, /t/ was recognized as a stop, an affricate, and was mostly considered as a fricative.

The positions where affrication can occur are in word initial and foot-initial, as in ([\#] in taken and [v_v́] in attack). "Foot-medial position allows fricatives, as do internal codas and word-final position" (Honeybone 2012, p.779). Debuccalization to [h], however, is limited yet popular in the appropriate environment where it can occur, according to Watson (2006b).With Debuccalization to /t/, it must occur in word-final and utterance-final position. In a polysyllabic word such as biscuit, /t/ must not occur in a stressed syllable, as in cigarette, for example. In a monosyllabic word, it must form part of to "monosyllabic function words (get and got) with short vowels" including not, what, that and at" (Watson 2006b, p.58). Watson (2006b) states that the weakest environment is [_\#], but this environment must be divided into two parts to take into consideration the syllable stress and the ordinary stress of the monosyllabic words.

\section{4 'Voicing' in the history of English}

Some letters in the English Language have undergone some changes. The use of $\langle\mathrm{u}\rangle$ and $\langle\mathrm{Z}\rangle$ instead of $\mathrm{ME}\langle\mathrm{f}\rangle$ and $\langle\mathrm{s}\rangle$ is one example. Lass (1991, p.93) calls this the "Old English Fricative Voicing". Honeybone (2012, p.781) refers to it as the "Southern English Fricative Weakening' (SEFW)". He believes this change was not related to any particular environment, and basically exists in all areas, and it falls under sonorization of the kind $\mathrm{f}, \theta, \mathrm{s}, \int>\mathrm{v}, \mathrm{\delta}, \mathrm{z}, 3$ on the lenition scales (Honeybone, 2005a; Honeybone 2012).

Final devoicing is a laryngeal change which is considered a case of lenition in a number of languages. Although the change consists of moving from voice to voiceless (the opposite of what's on the lenition scale), it is regarded as lenition because it occurs in the same environments as lenition (i.e. coda and words final positions). In this respect, English is unusual, since final obstruent voicing is apparent. Honeybone (2012, p.778) believes it is 'odd' to consider SEFW and 'Late Middle English Final Weakening' (LMEFW) as lenition, as the first one involves all segments and the second one involves final voicing. Some argue that this development is in fact regarded as lenition (Honeybone 2005a; Honeybone 2012).

\section{5. 'Rethinking the unity of lenition'}

A number of theoretical studies have been put together to consolidate lenition changes. Some of these studies include Dependency Phonology (Anderson and Ewen 1987), Government Phonology (Harris 1994) and Optimality Theory (Kirchner 2004), and many others. There is not one study that takes into account the whole aspect. Harris's definition of lenition is interesting, as he describes it as the 'loss of sub segmental material', but does not provide an explanation regarding affrication. According to Honeybone (2012, p. 783), all phonologists come to realize lenitions bear similarities, but have not yet figured out what it is. The environment in which lenition can and cannot occur may be a way to define lenition, although it would not be a 'phonological' definition. There is no earlier phonological theory that it stems from. Because this sort of definitions depend on elements that are related to the new methods of lenition, they are considered as 'historical phonological' definitions. Definitions that were based on particular environments encountered some problems due to these environments being slightly diverse.

Change and environment lend themselves to three distinct differences in types of relationship; conditioned changes, strongly unconditioned changes and weakly unconditioned changes (Honeybone 2012, p.783). Environments that are effected by neighbouring elements or other phonological environments are called 'conditional changes'. The strongly unconditioned changes are the changes were the phonological environment has no role in the changes, and finally, the weakly unconditioned changes"are not context-free in that they may not affect every occurrence of a segment, but which cannot be seen to be caused by the environment in which they occur" (Honeybone 2012, p.784). 
Honeybone $(2012$, p.784) notes that one approach to understanding lenition is to look at where lenition is restricted (inhibited), rather than looking at what causes lenition. The inhibition can be influenced by either prosodic or melodic environment. The strong positions, which include word-initial, post-coda and foot-initial, are restricted to prosodic. Lenition, however, can occur if these environments are weaker. If the weaker environments (prosodically-defined), which include word-final, medial/intervocalic and/or foot-internal, permit lenition to occur, then, the stronger positions can permit lenition to occur too. Weak positions do not promote lenition, but inhibit it less than strong positions do. Following this approach, prosodic and melodic environments ought to be divided, depending on the strength of the environment and how inhibited it is.

\subsection{The Effect of Melodic Inhibition in Medial d-spirantization and Liverpool Lenition}

According to Honeybone (2005b), when sub-segmental material of a nearby segment is shared with the leniting segment, change may be affected. Medial $d$-spirantization did not affect geminates. Clusters such as $/ \mathrm{nd} / \mathrm{and} / \mathrm{ld} /$ protected the $/ \mathrm{d} /$. In the lenition of Liverpool English, the homorganic nasal restricts this from happening. Melody or prosodic factors may result in lenitions being inhibited, sometimes both. In order for this to take place, significant hierarchies should be present within the prosodic and melodic environments (Honeybone 2012, p. 784). Change can only take place if it occurs in both these environments, and this is what lenition is believed to involve. He also notes that these kind of changes should be regarded as 'conditions' of lenition rather than 'definitions'. To really understand what lenition is, Honeybone (2012, p. 785) believes that it is necessarily to "recognize both the diversity of process types as well as the unity of patterning in lenition inhibition" (p.785).

\section{Conclusion}

A number of definitions regarding 'lenition' have been discussed in this paper, and these definitions varied among phonologists. It is clear that there are a number of disagreements amongst phonologists regarding these definitions. Despite these differences and disagreements, the concept of lenition and weakening in ongoing studies is universal in terms of definitions that are available in the literatures of theoretical phonology (Carr 1993,p.24; Kenstowicz 1994,p.35; Ewen and Hulst 2001,p.13; Gussmann 2002,p.137) and historical linguistics (Hock, 1991; Trask, 1996; Hoch and Joseph 1996; Campbell, 1998). With regards to the different types of lenition as mentioned in this study, lenition can be categorised as "loss of place features; debuccalization: $[\mathrm{t}]>[$ ? $],[\mathrm{f}]>[\mathrm{h}]$, depalatalization: $[\mathrm{n}]>[\mathrm{n}]$, delabialization: [ $\left.\mathrm{k}^{\mathrm{w}}\right]$ $>[\mathrm{k}]$, etc., loss of laryngeal features; devoicing: $[\mathrm{d}]>[\mathrm{t}]$, deaspiration: $\left[\mathrm{t}^{\mathrm{h}}\right]>[\mathrm{t}]$, or sonorization: spirantization: $[\mathrm{t}]>[\theta]$, gliding: [p] > [w], rhotacism: [s] > [r], etc." (Szigetvari 2008, p.110).

The idea of Lenition in English; the contemporary coronal stops, medial d-spirantization, lenition in Liverpool English, and 'voicing' in the history of the English Language are also discussed in this paper. With regards to the environments in which lenition can and cannot occur and why, there are a number of arguments in the theory of lenition regarding this topic, some of which have been discussed in this study.

\section{References}

Anderson, J. and Ewen, C. (1987).Principles of Dependency Phonology. Cambridge: Cambridge University Press.

Ashby, M. and Maidment, J. (2005).Introducing Phonetic Science. Cambridge: Cambridge University Press.

Campbell, L. (1998).Historical Linguistics: an Introduction. Edinburgh: Edinburgh University Press.

Carr, Philip, and Honeybone, P. (2007). 'English phonology and linguistic theory: an introduction to issues, and to Issues in English Phonology', Language Sciences 29, p.117-153.

Carr, Ph. (1993). Phonology. London: Macmillan.

Dobson, E.J. (1968). English Pronunciation 1500-1700. First/second edition. Two volumes. Oxford: Clarendon.

Ewen, C. and Harry, H. (2001). The Phonological Structure of Words: an Introduction. Cambridge: Cambridge University Press.

Foley, J.(1977).Foundations of Theoretical Phonology. Cambridge: Cambridge University Press.

Gussmann, E. (2002). Phonology: Analysis and Theory. Cambridge: Cambridge University Press.

Harris, J. (1990). Segmental complexity and phonological government. Phonology 7. p. 255-300.

Harris, J. (1994). English Sound Structure. Oxford: Blackwell

Hickey, R. (2009). 'Weak Segments in Irish English’, in Minkova (2009), p.116-29.

Hock, H. (1991). Principles of Historical Linguistics. Second edition. Berlin: Mouton de Gruyter.

Hock, H. H. and Joseph, B. (1996). Language History, Language Change and Language Relationship. Berlin: Mouton de Gruyter.

Honeybone, P. (2001). Lenition Inhibition in Liverpool English. English Language and Linguistics, 5, p.213-249.

Honeybone, P. (2008). Lenition, weakening and consonantal strength: Tracing concepts through the history of phonology. In Lenition and Fortition. Carvalho, J., Scheer, T. and Segeral, Ph. (eds). Studies in generative grammar 99. Mouton de Gruter: Berlin. 
Honeybone, P. (2012). Lenition in English. In The Oxford Handbook of The History of English. Nevalainen, T. and Traugott, E. (eds.). UK: Oxford University Press. Chapter 60. p.773-787.

Honeybone, P. (2001). 'Lenition Inhibition in Liverpool English', English Language and Linguistics 5, p. $213-249$.

Honeybone, P.(2002).Germanic Obstruent Lenition: some mutual implications of theoretical and historical phonology. Ph.D dissertation, University of Newcastle upon Tyne.

Honeybone, P. (2005a). Diachronic evidence in segmental phonology: the case of obstruent laryngeal specifications, in Marc. van Oostendorp and Jeroen van de Weijer (eds.), The Internal Organization of Phonological Segments. Berlin: Mouton de Gruyter, p. 319-354

Honeybone, P. (2005b). Sharing makes us stronger: process inhibition and segmental structure, in Philip Carr, Jacques Durand and Colin Ewen (eds.) Headhood, Elements, Specification and Contrastivity: Phonological Papers in Honour of John Anderson. Amsterdam: John Benjamins, p.167-192.

Hyman, L. (1975). Phonology: Theory and Analysis. New York: Holt, Rinehart and Winston.

Carvalho, J.,Scheer, T. and Segeral, Ph. (eds.) (2008). Lenition and Fortition. Studies in generative grammar 99. Mouton de Gruter: Berlin.

Kallen, J. (2005). Internal and external factors in phonological convergence: the case of English /t/ lenition, in P. Auer, F. Hinskens, and P. Kerswill (eds.), Dialect Change: the Convergence and Divergence of Dialects in Contemporary Societies. Cambridge: Cambridge University Press.

Kenstowicz, M. (1994). Phonology in Generative Grammar. Cambridge, MA: Blackwell

Kirchner, R.(1998).An Effort-Based Approach to Consonant Lenition. Ph.D dissertation, University of California, Los Angeles.

Kirchner, R. (2004). Consonant lenition, in B. Hayes, R. Kirchner and D. Steriade (eds.), Phonetically-based Phonology. Cambridge: Cambridge University Press.

Lass, R., and Anderson, J. (1975). Old English Phonology. Cambridge: Cambridge University Press.

Lass, R.(1984).Phonology: an Introduction to Basic Concepts. Cambridge: Cambridge University Press.

Lass, Roger (1991-1993). 'Old English fricative voicing unvisited', Studia Anglica Posnaniensia 35-37: 3-46.

Luick, K. (1914-1940). Historische Grammatik der englischen Sprache. Reprinted 1964. Oxford: Blackwell.

Martinet, A. (1952). Celtic lenition and Western Romance consonants. Language 28, p. 192- 217.

Mascaro, J.(1984). Continuant spreading in Basque, Catalan, and Spanish. In Language Sound Structure; Mark Aronoff and Richard Oehrle (eds.), p. 287-98. Cambridge, Mass: MIT Press.

Nevalainen, T. and Traugott, E. (eds.) (2012). The Oxford Handbook of the History of English. Oxford: Oxford University Press.

Odden, D. (2005). Introducing Phonology. Cambridge: Cambridge University Press.

Oxford English Dictionary (2006), http://www.oed.com/, accessed April 2015.

Scheer, T. and Segeral, Ph. (2008). Positional factors in lenition and fortition, in Brandao de Carvalho, Scheer, and Segeral (2008), p.131-172.

Szigetvari, P. (2008). 'What and where?', in Brandao de Carvalho, Scheer, and Ségéral (2008), p. 93-129.

Trask, R.L. (1996). A Dictionary of Phonetics and Phonology. London: Routledge.

Trask, R.L. (2000). The Dictionary of Historical and Comparative Linguistics. Edinburgh: Edinburgh University Press.

Watson, K. (2006a). 'Lenition and segmental interaction: evidence from Liverpool English (and Spanish), Glossa 1, p. 54-71.

Watson, K. (2006b). 'Phonological resistance and innovation in the North-West of England', English Today, p.55-61.

Watson, K. (2007). 'Liverpool English', Journal of the International Phonetics Association 37, p. 351-360. 